\title{
Mechanisms of heat damage in proteins
}

\author{
3.* Studies with $\epsilon-(\gamma$-L-glutamyl)-L-lysine \\ By P. E. WAIBEL† AND K. J. CARPENTER \\ Department of Applied Biology, University of Cambridge \\ (Received 6 fuly 1971-Accepted 25 October 1971)
}

\begin{abstract}
I. $\epsilon-(\gamma-\mathrm{L}-\mathrm{Glutamyl})-\mathrm{L}-\mathrm{lysine}$ was found to have a growth-promoting activity that was approximately equal to the equivalent quantity of L-lysine for both young rats and chicks receiving a lysine-deficient diet.

2. Small quantities of the compound were found in the plasma of both chicks and rats receiving it at the level of $0.4-0.5 \%$ on the diet, but none was detected in the rat urine and only a trace in the separated chick urine.

3. Direct intravenous infusion of glutarmyl-lysine into rats resulted in higher plasma concentrations; it is suggested that hydrolysis of the ingested peptides may occur largely in the intestinal wall.

4. The findings are discussed in relation to the earlier hypothesis that the formation of glutamyl-lysine cross-linkages in severely heated protein provides an explanation of their reduced nutritional value.
\end{abstract}

In the previous paper of this series (Bjarnason \& Carpenter, 1970), there was a discussion of the reasons for thinking that the most important reactions responsible for lowering the nutritional value of proteins that had been severely heated in the absence of reducing sugars (or other compounds with carbonyl groups) might be condensations between lysine and glutamine units in peptide chains to form $\epsilon$ - $(\gamma$-L-glutamyl)-lysine cross-linkings, together with similar reactions between lysine and asparagine units.

The present paper reports the results of an investigation designed to study whether or not the atypical dipeptide or isopeptide, $\epsilon$-( $\gamma$-L-glutamyl)-lysine can itself be used as a source of lysine by rats and chicks. Its resistance in vitro to a range of digestive enzymes has already been reported (Pisano, Finlayson \& Peyton, I969).

We have not attempted to synthesize the peptide, and its high cost from its only commercial manufacturer has limited the extent of our experiments.

EXPERIMENTAL

$\epsilon-(\gamma$-L-Glutamyl)-L-lysine hemi-hydrate (hereafter abbreviated to G-L) was obtained from Cyclo Chemical (Division Travenol Laboratories, Inc., Los Angeles) in two purchases, from their lots G-I245 and D-I944 respectively; each had been tested to be chromatographically pure. We confirmed that they both appeared on the amino acid analyser chromatograph at the same point as an authenticated sample kindly supplied from the University of Bradford. This material has a calculated molecular weight of 284.3 and should contain the equivalent of $5^{\circ} \cdot 4 \%$ lysine.

* Paper no. 2: Br. F. Nutr. (1970), 24, 313.

$\uparrow$ Present address: Department of Animal Science, University of Minnesota, St Paul, Minnesota 55 IOr, USA. 


\section{Analytical procedures}

For the determination of G-L, a Technicon AutoAnalyzer (Technicon Instruments Ltd, Chertsey, Surrey) was used with a $140 \mathrm{~cm}$ column packed with Technicon type ' $\mathrm{A}$ ' resin and kept at $60^{\circ}$. With our particular batch of resin we had not been successful in preliminary tests in achieving resolution with the standard Technicon buffer system used by Asquith, Otterburn, Buchanan, Cole, Fletcher \& Gardner (1970), who obtained good separation of G-L between leucine and tyrosine. The gradient elution system was therefore filled with a combination of buffers (Technicon Instruments Ltd, I966) originally designed by Burns, Curtis \& Kacser (I965) to open out the chromatogram between isoleucine and ammonia. Under these conditions our peak for methionine appeared $5 \mathrm{~h}$ (or a little less) after the beginning of the run, followed (with the time from methionine in $\mathrm{min}$ ) by G-L (Io), alloisoleucine (I5), isoleucine (28), leucine (39), norleucine (50) and tyrosine (75). All the peaks were clearly separated. The relative peak area given by $0 \cdot 1 \mu \mathrm{mol} \mathrm{G-L}$ was approximately $\mathrm{r} \cdot 6$ times that given by $\circ \cdot \mathrm{r} \mu \mathrm{mol}$ glutamic acid.

\section{Animal experiments}

Growth assays for lysine. For the rat assay the diet of Bjarnason \& Carpenter (1969) was used except that maize starch was replaced by sucrose and the vitamin mix was modified to supply altogether $(\mathrm{mg} / \mathrm{kg}$ diet): thiamin hydrochloride 4 , riboflavin 5 , pyridoxine hydrochloride 6 , nicotinic acid 20 , calcium pantothenate $\mathrm{I} 2$, biotin $\mathrm{I}$, cyanocobalamin 0.02 , choline chloride 1000 , Rovimix A (50 i.u. vitamin $\mathrm{A} / \mathrm{mg}$ ) 46 , Rovimix $\mathrm{D}_{3}$ (roo i.u. cholecalciferol $/ \mathrm{mg}$ ) 3, Rovimix E (10\% DL- $\alpha$-tocopheryl acetate) 600. Rovimix supplements were supplied by Roche Products Ltd, Welwyn Garden City, Herts. Supplements for the test diets (shown in Table I) were added at the expense of sucrose.

Female rats of the CFY strain (Carworth Europe Ltd, Huntingdon) were purchased, at $24 \mathrm{~d}$ of age and weighing $45-5 \circ \mathrm{g}$; they received the unsupplemented basal diet for $3 \mathrm{~d}$. They were then randomized and caged in pairs, and allotted to one of the experimental diets for a further $7 \mathrm{~d}$. Weight gain and food consumption were measured daily. The response of the rats was measured as ' $\mathrm{g}$ weight gain/g food eaten' and the potency of G-L was compared with that of lysine by the slope-ratio procedure described by Finney (1964).

For the chick assay we used a slight modification of a previously published diet (Carpenter, March, Milner \& Campbell, 1963) composed of (\%): sesame-seed meal 20, ground whole wheat 20 , partly hydrogenated vegetable fat (Trex; J. Bibby and Sons Ltd, Liverpool) 1o, zein 3, grass meal 2, powdered cellulose 2, steamed boneflour 2, limestone flour I, DL-methionine 0.25 , L-leucine 0.06 , vitamin mix, mineral mix and sucrose to Ioo. The vitamin mix supplied (mg/kg diet): Rovimix A (5० i.u. vitamin $\mathrm{A} / \mathrm{mg}$ ) 120, Rovimix $\mathrm{D}_{3}$ (100 i.u. cholecalciferol/mg) 10, Rovimix E (10\% DL$\alpha$-tocopheryl acetate) 200, menaphthone I, riboflavin Io, calcium pantothenate 20, nicotinic acid 5o, thiamin hydrochloride 6 , pyridoxine hydrochloride 6 , folic acid 4 , 


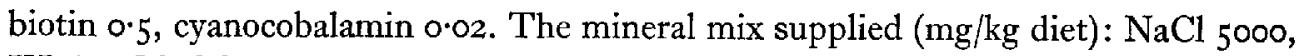
$\mathrm{KI} 6 \cdot 5, \mathrm{MnSO}_{4} \cdot 4 \mathrm{H}_{2} \mathrm{O} 300, \mathrm{ZnO} 60$.

Chicks were received at I-d-old, and caged in pairs; they were fed for $3 \mathrm{~d}$ on the basal diet supplemented with $0.3 \%$ lysine (as $0.375 \%$ lysine hydrochloride). Those showing medial weight gains in this period were then randomized into thirty-six cages of two chicks each; six cages were allotted to the basal diet alone and three cages were allotted to each of ten dietary treatments. Of these ten only the six treatments set out in Table 2 will be considered in the present paper.

The experimental period consisted of $3 \mathrm{~d}$ and weight gains and food consumption were recorded. The results were anlysed as for the rat assay.

Plasma samples for analysis. At the end of each growth assay, animals from the treatments receiving the highest level of G-L and the corresponding level of lysine were killed with diethyl ether, their thoracic cavity was opened and blood was taken from the heart into a heparinized syringe. This was centrifuged at $2000 \mathrm{~g}$ for $25 \mathrm{~min}$; I ml plasma was taken and mixed with $0.25 \mathrm{ml}$ sulphosalicylic acid ( $15 \%, \mathrm{w} / \mathrm{v})$, shaken thoroughly and re-centrifuged. The centrifugate was stored in a deep-freeze. For analysis $0.5 \mathrm{ml}$ was placed direct on the chromatograph column.

Urine collection. Separate trials were carried out for the collection of urine. The same basal diet was used as for the growth assay except that, as wheat gluten was unavailable, it was replaced by maize gluten. The rats used were also of the same strain but had been reared on a control diet to approximately roo $\mathrm{g}$ weight before use. Two rats were used and were allowed to eat ( $a d l i b$.) for four I $h$ periods each day in separate cages outside their metabolism cage. The experiment continued for $4 \mathrm{~d}$. On days $\mathrm{I}$, 3 and 4 each rat received the basal diet supplemented with $0.25 \%$ lysine hydrochloride; on day 2 the diet was supplemented with $0.5 \% \mathrm{G}-\mathrm{L}$. On day 2 , each rat ate $9.5 \mathrm{~g}$ diet, which was equivalent to an intake of $48 \mathrm{mg} \mathrm{G}-\mathrm{L}$.

Urine was collected separately in each $24 \mathrm{~h}$, made up to $50 \mathrm{ml}$ with washings, filtered, preserved with thymol and stored frozen until analysis could be commenced, when $0.3-0.5 \mathrm{ml}$ was applied to the column.

The chicks used for urine analysis were kept on a standard diet until they weighed $500-55^{\circ} \mathrm{g}$; four were then operated on by the procedure of Newberne, Laerdal \& O'Dell (1957) to exteriorize their ureters, and the two which gave the best separation of urine were used for the experiment. They then received the basal diet alone for days I, 2, 4 and 5 . On day 3 each bird received and consumed $5^{\circ} \mathrm{g}$ basal diet supplemented with $5 \circ \mathrm{mg}$ glutamyl-lysine. Each day's urine from one bird was again made up to $50 \mathrm{ml}$ and $0.5 \mathrm{ml}$ was used for chromatographic analysis.

Intravenous infusion. Six rats from a stock colony and weighing $170-200 \mathrm{~g}$ were

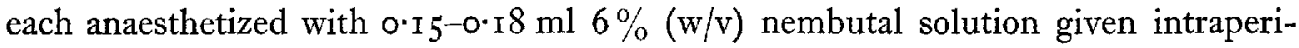
toneally. The abdomen of each was then opened and either the blood supply to the kidneys was ligatured or a similar 'sham' operation was performed. A jugular vein was then exposed and I $\mathrm{ml} 0.9 \%$ (w/v) saline containing I $\mathrm{mg} \mathrm{G}-\mathrm{L}$ was then uniformly infused into it, through a polyethylene tube by a peristaltic pump over a $20 \mathrm{~min}$ period. One minute after the infusion was stopped, the chest cavity was opened and blood was withdrawn from the heart for plasma analysis as described above. Larger rats had to 
Table I. Response of rats receiving a lysine-deficient diet to either lysine or glutamyl-lysine

\begin{tabular}{|c|c|c|c|}
\hline \multicolumn{3}{|c|}{ Test supplement } & \multirow[b]{2}{*}{$\begin{array}{l}\text { Wt gain } \\
\text { of rats } \\
\text { (g)/g food } \\
\text { eaten }\end{array}$} \\
\hline Description & $\begin{array}{c}\text { Level of } \\
\text { inclusion } \\
\text { (mg/roo } \mathrm{g} \\
\text { diet) }\end{array}$ & $\begin{array}{l}\text { Lysine } \\
\text { equivalents } \\
\text { contributed } \\
\text { (mg/roo g) }\end{array}$ & \\
\hline None (negative control) & - & - & $0.19 I^{*}$ \\
\hline \multirow{3}{*}{ L-Lysine hydrochloride } & 62.5 & 50 & 0.233 \\
\hline & $\begin{array}{l}125 \\
250\end{array}$ & $\begin{array}{l}100 \\
200\end{array}$ & $\begin{array}{l}0.280 \\
0.349\end{array}$ \\
\hline & 375 & 300 & 0.422 \\
\hline \multirow{2}{*}{$\epsilon$-( $\gamma$-L-Glutamyl)-L-lysine } & $\int 200$ & $102 \cdot 5$ & 0.279 \\
\hline & $\{400$ & 205 & $0 \cdot 343$ \\
\hline \multicolumn{3}{|c|}{ Pooled estimate of the standard error of treatment means } & \pm 0.033 \\
\hline
\end{tabular}

* This treatment had twice as many replications as the others and the mean had a standard error of \pm 0.024 .

Table 2. Response of chicks receiving a lysine-deficient diet to either lysine or glutamyl-lysine

Test supplement

\begin{tabular}{|c|c|c|c|}
\hline Description & $\begin{array}{c}\text { Level of } \\
\text { inclusion } \\
\text { (mg/roo g } \\
\text { diet) }\end{array}$ & $\begin{array}{c}\text { Lysine } \\
\text { equivalents } \\
\text { contributed } \\
\text { (mg/100 g) }\end{array}$ & $\begin{array}{l}\text { Wt gain } \\
\text { of rats } \\
\text { (g) } / \mathrm{g} \text { food } \\
\text { eaten }\end{array}$ \\
\hline \multirow[t]{2}{*}{ None (negative control) } & - & 一 & $0.323^{*}$ \\
\hline & $(75$ & 60 & 0.361 \\
\hline \multirow{2}{*}{ L-Lysine hydrochloride } & I50 & 120 & 0.443 \\
\hline & $\left\{\begin{array}{l}300 \\
600\end{array}\right.$ & $\begin{array}{l}240 \\
480\end{array}$ & $\begin{array}{l}0.467 \\
0.558\end{array}$ \\
\hline$\epsilon-(\gamma$-L-Glutamyl)-L-lysine & $\left\{\begin{array}{l}233 \cdot 5 \\
467\end{array}\right.$ & $\begin{array}{l}120 \\
240\end{array}$ & $\begin{array}{l}0.398 \\
0.460\end{array}$ \\
\hline \multicolumn{3}{|c|}{ Pooled estimates of the standard error of treatment means } & \pm 0.027 \\
\hline
\end{tabular}

* This treatment had twice as many replications as the others and the mean had a standard error of \pm 0.019 .

be used for this experiment than for the growth assay in order to allow insertion of a tube into a vein. Since they had nearly twice the metabolic body size $\left(W^{0.67}\right)$, the rate of infusion of G-L was chosen to be also nearly twice that estimated to correspond to the hourly ingestion of G-L by the rats in the growth assays.

\section{RESULTS}

Growth assays

The results of the rat and chick assays are summarized in Tables $\mathrm{I}$ and 2 respectively. 'The estimated potency of G-L was $0.49\left( \pm 0 . I_{5}\right)$ that of lysine itself for rats and $0.51( \pm 0.15)$ for chicks. The theoretical potency if all the lysine in the peptide 
were available is 0.514 . Both estimates correspond therefore to almost complete availability of the lysine in the peptide. The standard errors of the estimates are large, as was to be expected from the limited number of replicates.

\section{Plasma analysis}

Neither of the two samples of rat plasma nor of the two chick samples from control treatments showed any trace of a peak at the position of G-L. However, an addition of $0.3 \mu \mathrm{g} / \mathrm{ml}$ of G-L to a control plasma sample gave a clearly visible peak. The three samples from rats that had received the highest level in the growth assay all showed peaks, equivalent to $\mathrm{I} \cdot 4,4 \cdot 2$ and $\mathrm{I} \cdot 3 \mu \mathrm{g} \mathrm{G}-\mathrm{L} / \mathrm{ml}$ plasma respectively. Three corresponding samples from chicks also showed peaks corresponding to $0.7,3.4$ and $2.0 \mu \mathrm{g} / \mathrm{ml}$ respectively.

The following approximate calculations are an attempt to relate the order of magnitude of total G-L in the plasma to the rate of ingestion of the compound:

$\begin{array}{lcc} & \text { Rats } & \text { Chicks } \\ \text { Approximate body-weight at sampling }(\mathrm{g}) & 70 & 75 \\ \text { Plasma volume (at } 5 \mathrm{ml} / \mathrm{I00} \mathrm{g} \text { body-weight) } & 3.5 & 3.75 \\ \text { Mean G-L concentration in plasma }(\mu \mathrm{g} / \mathrm{ml}) & 2.3 & 2.0 \\ \text { Total plasma G-L }(\mu \mathrm{g}) & 8 & 7.5 \\ \text { Food intake } / 24 \mathrm{~h}(\mathrm{~g}) & 10 & 14 \\ \text { Dietary G-L }(\mu \mathrm{g} / \mathrm{g} \text { food) } & 4000 & 4670 \\ \text { G-L intake }(\mu \mathrm{g} / \mathrm{h}) & 1670 & 2700\end{array}$

It appears, therefore, that the quantity of G-L found in the plasma corresponds to $0.5 \%$ or less of the hourly dietary intake in each species. Even if it were distributed uniformly throughout the whole animal in the same concentration as in the plasma, the total present would only correspond to $10 \%$ or less of the hourly intake.

From the experiments in which G-L was given by intravenous infusion, the final plasma concentrations in the intact rats were $1 \mathrm{r} \cdot 5$ and $16.7 \mu \mathrm{g} / \mathrm{ml}$ (the third sample having been lost), and for the rats with ligatured kidneys were $20^{\circ} 4, x^{\circ} 3$ and $21.2 \mu \mathrm{g}$ / $\mathrm{ml}$. The estimated total plasma contents were 100 and $\mathrm{I} 65 \mu \mathrm{g}$ for the intact rats and 205,140 and $205 \mu \mathrm{g}$ for the ligatured rats. In every instance the whole of the $1000 \mu \mathrm{g}$ G-L administered might be accounted for within the rat's tissues, even if it were present elsewhere at lower concentrations than in the plasma.

\section{Urine analysis}

None of the urine samples from rats receiving G-L in their diet showed the presence of $G-L$, although addition of the compound to a control urine sample gave $98 \%$ of the expected value. If a quantity corresponding to only $0.25 \mathrm{mg}$ had been present in a day's excretion (made up to $50 \mathrm{ml}$ ) its peak should have been clearly visible. Since the intake per head in this experiment was $48 \mathrm{mg} / 24 \mathrm{~h}$ it appears that less than $0.5 \%$ of the dose was being excreted in the urine in that period or in the following $24 \mathrm{~h}$.

The analyses of chick urine showed no peak at the G-L position on day I (i.e. before dosing). For the urine obtained during the $24 \mathrm{~h}$ of dosing, peaks corresponding to 0.37 and $0.21 \mathrm{mg}$ respectively for the day's output from each bird were measured. 
Even if the analytical error, and losses in collection of urine, were such that the true values were as high as $0.5 \mathrm{mg} / \mathrm{bird}$ per $\mathrm{d}$, this would still correspond to no more than $\mathrm{I} \%$ of the quantity ingested.

\section{DISCUSSION}

The first result, that young rats can apparently utilize G-L almost completely as a source of dietary lysine, is only a confirmation of a finding that has now been published by Mauron (I970). Whatever the mechanism for this, it is, apparently, shared by chicks. It is not surprising therefore that very little G-L was recovered in the urine of dosed animals.

Since treatment in vitro with a variety of digestive enzymes has been reported not to release lysine from this peptide bond, though other peptide linkages occurring in the protein tested have all been hydrolysed (Pisano et al. I969; Asquith et al. 1970) it is likely that the molecule remains unattacked in the lumen of the gut and is absorbed as such, in the same way as normal dipeptides. The latter are believed to be completely hydrolysed within the intestinal wall since none are found in the portal vein (cf. Dawson \& Porter, I962). Our finding of G-L in plasma indicates that its hydrolysis is, at any rate, incomplete within the intestinal wall.

Both rats (Paik \& Benoiton, 1963) and chicks (Leclerc $\&$ Benoiton, 1968) possess kidney enzymes that will hydrolyse a range of molecules in which lysine is linked through its $\epsilon$-amino group. However, it seems likely that the hydrolysis of orally ingested G-L occurs largely in the wall of the gut rather than in the kidney or other tissues since the level of circulating peptide in short-term experiments has risen to much higher levels when G-L has been perfused direct into the blood-stream of rats than it does when G-L is ingested by rats with their food.

\section{Heat-damaged protein}

In the previous paper of the series (Bjarnason \& Carpenter, 1970) it had been hypothesized that, where there were no carbonyl compounds present to permit Maillard reactions, the formation of G-L (and aspartyl-lysine) cross-linkages in severely heated proteins could explain their generally lower nutritional value. This hypothesis is not vitiated by the finding that G-L itself is nutritionally available as a source of lysine, since the presence of such cross-linkages can still be thought of as hindering the digestion of proteins (cf. Ford, 1965 ).

It has been observed with severely heated animal proteins (essentially free from reducing sugars or oxidized fat) that the nutritional availabilities of lysine, methionine and tryptophan are all reduced to a similar degree (Miller, Carpenter \& Milner, 1965; Varnish \& Carpenter, 1970). One would only expect this to be so if there is nearly equal availability of all three amino acids in the proportion of dietary protein that is finally digested - in other words, if the lysine released were in as utilizable a state as the methionine and tryptophan. The present results seem therefore to be consistent with the earlier hypothesis, though they do not directly support (nor detract from) the possibility of its being correct. 
We thank Drs R. S. Asquith and M. S. Otterburn of the School of Colour Chemistry, University of Bradford, who gave us information before publication and subsamples of authenticated glutamyl-lysine, also Dr D. W. T. Crompton who operated on chicks to exteriorize their ureters and Dr R. H. S. Carpenter who carried out the intravenous infusion of rats.

\section{REFERENCES}

Asquith, R. S., Otterburn, M. S., Buchanan, J. H., Cole, M., Fletcher, J. C. \& Gardner, K. L. (I97o). Biochim. biophys. Acta 221, 342.

Bjarnason, J. \& Carpenter, K. J. (1969). Br. F. Nutr. 23, 859.

Bjarnason, J. \& Carpenter, K. J. (1970). Br. F. Nutr. 24, 3 I3.

Burns, J. A., Curtis, C. F. \& Kacser, H. (1965). F. Chromat. 20, 310.

Carpenter, K. J., March, B. E., Milner, C. K. \& Campbell, R. C. (1963). Br. F. Nutr. 17, $3 \circ 9$.

Dawson, R. \& Porter, J. W. G. (1962). Br. F. Nutr. 16, 27.

Finney, D. J. (I964). Statistical Methods in Biological Assay and ed. New York: Hafner Publishing Co.

Ford, J. E. (1965). Br. F. Nutr. 19, 277.

Leclerc, J. \& Benoiton, L. (1968). Can. F. Biochem. 46, 47I.

Mauron, J. (1970). F. int. Vitaminol. 40, 209.

Miller, E. L., Carpenter, K. J. \& Milner, C. K. (1965). Br. F. Nutr. 19, 547.

Newberne, P. M., Laerdal, O. A. \& O'Dell, B. L. (1957). Poult. Sci. 36, 821.

Paik, W. K. \& Benoiton, L. (r963). Can. F. Biochem. Physiol. 4I, I643.

Pisano, J. J., Finlayson, J. S. \& Peyton, M. P. (1969). Biochemistry, Easton 8, 87 r.

Technicon Instruments Ltd (1966). Techniques in Amino Acid Analysis p. I15. Chertsey, Surrey: Technicon Instruments Ltd.

Varnish, S. A. \& Carpenter, K. J. (1970). Proc. Nutr. Soc. 29, 45 A. 